\title{
Mountain uplift and the glaciation of North America - a sensitivity study
}

\author{
G. L. Foster ${ }^{1}$, D. J. Lunt ${ }^{2}$, and R. R. Parrish ${ }^{3}$ \\ ${ }^{1}$ School of Ocean \& Earth Science, National Oceanography Centre, Southampton, University of Southampton, Waterfront \\ Campus, Southampton SO14 3ZH, UK \\ ${ }^{2}$ School of Geographical Sciences, University of Bristol, University Road, Bristol, BS8 1SS, UK \\ ${ }^{3}$ NERC Isotope Geosciences Laboratory, British Geological Survey, Keyworth, Nottingham, NG12 5GG, UK
}

Received: 22 October 2009 - Published in Clim. Past Discuss.: 27 November 2009

Revised: 7 October 2010 - Accepted: 10 October 2010 - Published: 25 October 2010

\begin{abstract}
The Miocene ( $\sim 24$ to $\sim 5$ million years ago) was a period of relative global warmth compared to the Quaternary ( $\sim 2$ million years ago to present; e.g. Zachos et al., 2001) and was characterised by the intermittent glaciation of Antarctica only. Paradoxically, the majority of available proxy data suggest that during the Miocene, $p \mathrm{CO}_{2}$ was similar, or even lower, than the pre-industrial levels (280 ppmv; Pagani et al., 1999; Pearson and Palmer, 2000; Kürschner et al., 1996, 2008) and at times probably crossed the modelled threshold value required for sustained glaciation in the Northern Hemisphere (DeConto et al., 2008). Records of ice rafted debris and the oxygen isotope composition of benthic foraminifera suggest that at several times over the last 25 million years substantial amounts of continental ice did build up in the Northern Hemisphere but none of these led to prolonged glaciation. In this contribution, we review evidence that suggests that in the Miocene the North American Cordillera was, at least in parts, considerably lower than today. We present new GCM simulations that imply that small amounts of uplift of the North American Cordillera result in significant cooling of the northern North American Continent. Offline ice sheet modelling, driven by these GCM outputs, suggests that with a reduced topography, inception of the Cordilleran ice sheet is prohibited. This suggests that uplift of the North American Cordillera in the Late Miocene may have played an important role in priming the climate for the intensification of Northern Hemisphere glaciation in the Late Pliocene.
\end{abstract}

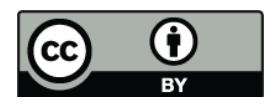

Correspondence to: G. L. Foster (gavin.foster@noc.soton.ac.uk)

\section{Introduction}

The Cenozoic is a time period characterised by a gradual deterioration of global climate which culminated in bipolar continental glaciation around 3 million years ago (Fig. 1; Mudlesee and Raymo, 2005). The near accepted paradigm invokes a gradual decline in $p \mathrm{CO}_{2}$ caused by enhanced silicate weathering (Raymo and Ruddiman, 1992; Raymo et al., 1988 ) as the driver for this well-documented climate change. Reconstructing the concentration of atmospheric $\mathrm{CO}_{2}$ beyond the reach of the Quaternary ice cores is, however, a notoriously difficult task. Nonetheless, there is a growing consensus that $p \mathrm{CO}_{2}$ did decline over the Cenozoic, but not exactly sympathetically with climate as the paradigm suggests (Fig. 1). This is likely because the $p \mathrm{CO}_{2}$ records are not perfect (e.g. Pagani et al., 2005) and other phenomenon such as ocean circulation, continental configuration, and surface albedo (vegetation and ice coverage) also influence climate. For instance, it has been known for some time that the rise and fall of mountain ranges and the formation of mountainous plateau regions on geological timescales (e.g. the Tibetan Plateau and North American Cordillera) can directly influence global climate (e.g. Ruddiman et al., 1989). So much so that it has been suggested that a reorganisation of atmospheric and oceanic circulation as a direct consequence of global Late Cenozoic mountain formation may have played an important part in the Late Cenozoic climatic deterioration which led to the intensification of Northern Hemisphere glaciation (INHG) in the Late Pliocene (Ruddiman et al., 1989; Mudlesee and Raymo, 2005). The importance of topography was recently highlighted by DeConto et al. (2008) who showed that in climate model simulations with globally reduced topography (half modern topography), the threshold

Published by Copernicus Publications on behalf of the European Geosciences Union. 


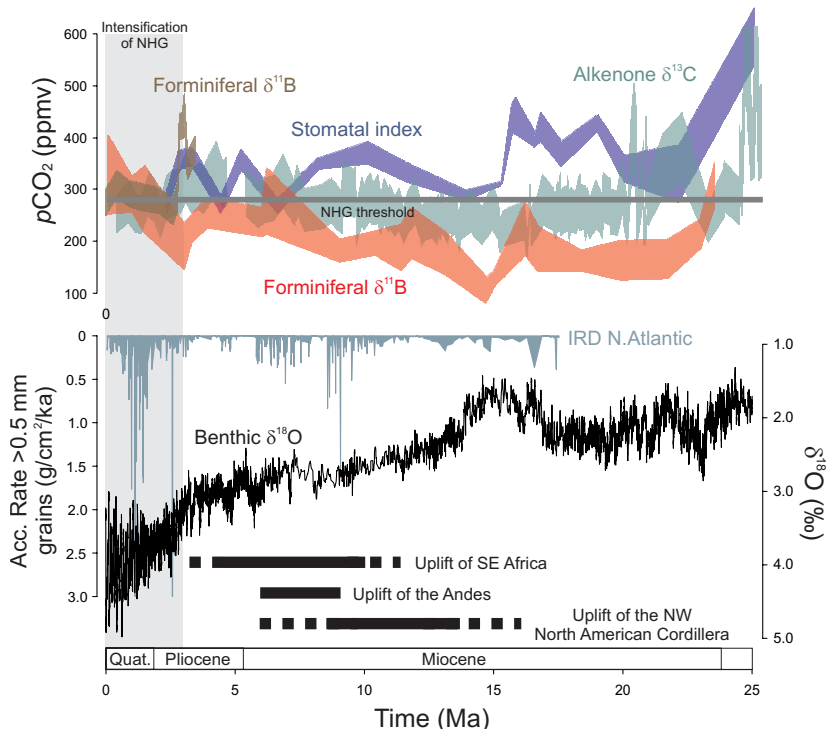

Fig. 1. Miocene, Pliocene and Quaternary $p \mathrm{CO}_{2}$ (top) and climate records. The atmospheric concentration of $\mathrm{CO}_{2}$ (top) during this time period is reconstructed using stomatal index of fossil leaves (blue; Kürschner et al., 2008; Kürschner et al,. 1996), the $\delta^{13} \mathrm{C}$ of marine alkenones (green; Pagani et al., 1999; Pagani et al., 2009) and the $\delta^{11} \mathrm{~B}$ of marine planktic foraminifera (red - Pearson and Palmer, 2000; brown - Seki et al., 2010). The threshold $p \mathrm{CO}_{2}$ value necessary for sustained glaciation in the Northern Hemisphere is shown as a horizontal grey band (DeConto et al., 2008). Also shown is a record of ice rafted debris (IRD) in the North Atlantic (middle; ODP Site 151-909; Winkler, 1999) and the global compilation of benthic foraminifera $\delta^{18} \mathrm{O}$ of Zachos et al. (2008; bottom). The vertical grey bar shows the time period when there was sustained glaciation in the Northern Hemisphere, note the sharp decline in $\delta^{18} \mathrm{O}$ and increase in IRD at this time. Also shown by horizontal black bands are the timing of uplift of the NW North American Cordillera as reviewed here as well as Andean (Garizone et al., 2008) and SE African uplift (Sepulchre et al., 2006 and references there in).

$p \mathrm{CO}_{2}$ value required to trigger the INHG was lowered from 280 ppmv to $140-210$ ppmv (compare their supplementary Fig. 3 with Fig. 3 in their main paper). These general circulation model (GCM)-ice sheet model simulations confirm early modelling studies (e.g. Kutzbach et al., 1989) that first documented the importance of global topography in determining climate and the potential role surface uplift may play in triggering climate change. However the approach of DeConto et al. (2008) is rather simplistic and it is considered very unlikely that topography increased globally sometime in the Late Cenozoic (England and Molnar, 1990). Nonetheless, in the last two decades, it has come to light that a relatively large number of regions underwent uplift in the Late Miocene. For instance, significant surface uplift $(\sim 2000 \mathrm{~m})$ occurred in the last 10 million years in the Andes (e.g. Garizone et al., 2008). Similarly, although the Tibetan plateau is thought to have remained at the same height since its inception, it gradually ex- tended northwards and eastwards throughout this time period (Rowley and Garizone, 2007). Also, Supulchre et al. (2006; and references there in) document regional scale uplift in Southern Africa from $\sim 12 \mathrm{Ma}$.

\subsection{Climatic and atmospheric influence of the North American Cordillera}

Topography plays a particularly crucial role in controlling climate over North America. General circulation models, run with a much reduced orography relative to the modern, highlight that without the current north-south mountain barrier to westerly atmospheric circulation that exists along the west coast of the North America (herein referred to as the North American Cordillera), the winters of NE North American continent would be significantly warmer and the continental interior of the US would be much wetter than today (Kutzbach et al., 1989; Seager et al., 2002). Indeed, contrary to popular belief, the relative frigidity of the winter time climate in NE North America has more to do with the coastal mountains of the North American Cordillera influencing atmospheric circulation than it does with the Gulf Stream providing warmth to maritime Europe (Seager et al., 2002). In the absence of the present mountain barrier, atmospheric circulation would be more or less zonal (as it is in the Southern Hemisphere around the Antarctic continent). However, with the significant mountain barrier atmospheric Rossby waves are generated and the jet-stream is deflected down stream of the barrier stabilising a cooler polar winter air mass over NE North America (e.g. Seager et al., 2002). Broccoli and Manabe $(1992,1997)$ also suggested that, because the tracks of major storms responsible for much of the mid-latitudes' precipitation are parallel to the upper tropospheric jet, in the absence of the mountain barrier moisture transport to the continental interior would be enhanced and, consequently, the prairies of the continental interior would also be much wetter.

\subsection{Topographic evolution of the North American Cordillera}

It is now relatively well established that parts, but not all, of the North American Cordillera have been areas of high elevation since their formation in the Early Cenozoic (e.g. Wolfe et al., 1998; Horton et al., 2004; Kent-Corson et al., 2006). Due to the nature of North American tectonics, continental material has been accreting to the west coast of the North American Continent since the Jurassic (150-205 Ma), with the most recent major orogenic event being the Laramide Orogeny that climaxed at $\sim 75 \mathrm{Ma}$ (Burchfiel et al., 1992). Parts of this orogenic area subsequently experienced tectonic collapse initiating in the north as early as $55 \mathrm{Ma}$ (Parrish et al., 1988) and reaching the south (central Nevada) by $35 \mathrm{Ma}$ (Kent-Corson et al., 2006 and references therein) forming a number of large basins separated by mountain ranges (e.g. 
Hyndman et al., 2005). The height of the ranges prior to the Pliocene is known in a number of places from paleobotanical analysis (e.g. Wolfe et al., 1998) and through numerous studies using $\delta^{18} \mathrm{O}$ based paleoaltimetry (e.g. Kent-Corson et al., 2006; Horton et al., 2004). These studies have been interpreted as indicating that surface uplift propagated from north (British Columbia) to south (Nevada) from the Eocene to Oligocene, accompanied by the development of topographic highs and magmatism associated with the delamination of the mantle lithosphere (Kent-Corson et al., 2006; Horton et al., 2004). The prevailing view is that although some Late Cenozoic surface uplift may have occurred (e.g. see Sahagian et al., 2002), the Colorado Plateau and much of the rest of the North American Cordillera have been long standing features of high elevation $(>2 \mathrm{~km})$ and, if anything, have become lower since the Middle Miocene. The Basin and Range and the Sierra Nevada have similar histories with both ranges being extant in the Miocene and either dropping in height since then (Wolfe et al., 1998; Horton et al., 2004) or, for the Sierra Nevada, maintaining a similar to present altitude (Chamberlain and Poage, 2000).

However, a growing body of evidence suggests that the coastal mountain ranges of the NW North American Cordillera (i.e. the Cascades of the northwestern US, the Coast Range Mountains of British Columbia (BC), St Elias Mountains of NW BC to SE Alaksa and Coast Range of Alaska) did indeed start to develop in the Middle to Late Miocene and alpine glaciation in these ranges is thought to have begun at around 7-9 million years ago (Denton and Armstrong, 1969; Clague, 1991) which is likely coincident with their attainment of near-present height.

The data pertaining to the elevation of the NW North American Cordillera comes in three strands that will be discussed here in turn - (i) paleobotanical and oxygen isotope paleoaltimetry; (ii) geological indicators of uplift, (iii) thermochronological indicators of rock uplift. The geographic locations that are relevant to this evidence are highlighted in Fig. 2.

Paleobotanical data on Miocene-Pliocene flora (Martin and Rouse, 1966; Rouse and Mathews, 1979; White et al., 1997) has been recovered from the lee of the Alaskan Coast Range, St. Elias Mountains, and Coast Mountains of Canada (Fig. 2). These preserve evidence of both global climatic trends, for example general Cenozoic cooling and the Pliocene warm interval (White et al., 1997), as well as more regional climatic effects indicative of increased seasonality and more continental - colder - drier climate since $7 \mathrm{Ma}$ ago in the lee of Alaskan and St. Elias Ranges (White et al., 1997) and $11 \mathrm{Ma}$ in the lee of the Canadian Coast Range (Martin and Rouse, 1966; Rouse and Mathews, 1979), consistent with the development of a significant rain shadow at this time. This view is also supported by oxygen isotope analysis. Kohn et al. (2002), using fossil herbivore teeth from the Oregon Plateau (Fig. 2), show an isotopic change consistent with the development of the modern topographic

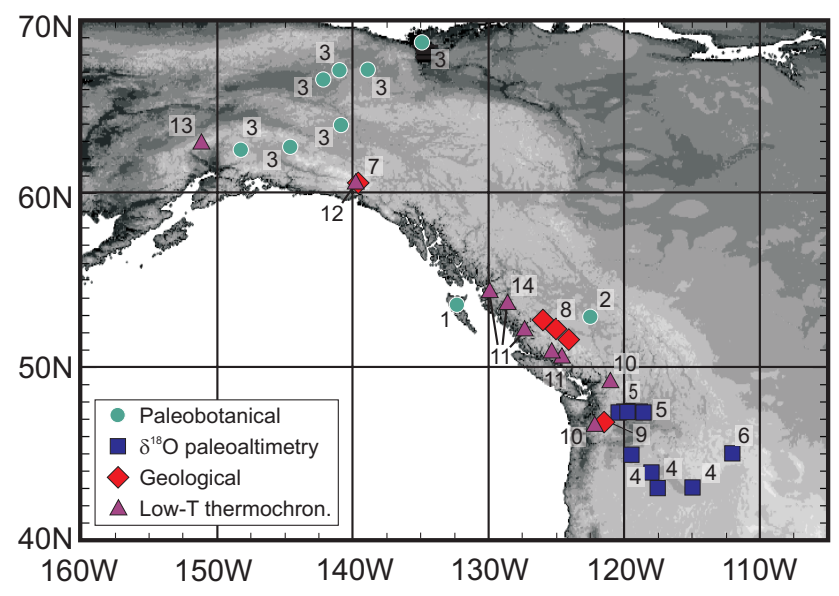

Fig. 2. Digital elevation model of the North American Continent showing the location of much of the published data used in the text divided according to the data type. 1 - Martin and Rouse (1966), 2 - Rouse and Mathews (1979), 3 - White et al. (1997), 4 - Kohn et al. (2002), 5 - Takeuchi and Larson (2005), 6 - Kent-Corson et al. (2006), 7 - Campbell and Dodds (1978), 8 - Parrish (1983), 9 Swanson (1997), 10 - Reiners et al. (2002), 11 - Parrish (1983), 12 - O'Sullivan and Currie (1996), 13 - Fitzgerald et al. (1995), 14 Farley et al. (2001).

coastal barrier in Oregon (from the Cascades) between 7.2 and $3 \mathrm{Ma}$. Oxygen data in clay minerals in paleosols in eastern Washington State (Fig. 2) show a similar effect beginning sometime after $11 \mathrm{Ma}$ consistent with the development of the modern $\sim 1.5 \mathrm{~km}$ of relief at this time (Takeuchi and Larson, 2005). In a paleosol based reconstruction of precipitation patterns in Oregon (Fig. 2), also in the lee of the Cascades, Retallack (2004) noted a drying trend initiating shortly after $\sim 15 \mathrm{Ma}$. Furthermore, to the east in Nebraska, Passey et al. (2002) note a decline in the $\delta^{18} \mathrm{O}$ of fossil equid teeth indicative of drying at 13-10 Ma, and in Montana and Idaho (Fig. 2) Kent-Corson et al. (2006) show a near synchronous shift in paleosol $\delta^{18} \mathrm{O}$ also thought to be related to formation of the Cascade Mountains. In total, a number of studies support the development of the modern topographic barrier and associated rain shadow in the NW of the North American continent in its near entirety sometime shortly after the Mid- to Late Miocene (i.e. after 15-10 Ma).

Sedimentary and volcanic deposits of Late Cenozoic age also have a bearing on this problem and support these conclusions. Miocene (7-14 Ma) volcanic rocks erupted in part on relatively level and low-relief erosion surfaces are exposed both on the central plateau in Canada as well as at significant elevations in the St. Elias Mountains (Campbell and Dodds, 1978) and on the east side of the southern British Columbia Coast Range Mountains (Parrish, 1983; Souther and Yorath, 1992; Fig. 2). In several places, $\sim 7 \mathrm{Ma}$ sheets of lava have been tilted (with local folding) up to $15-20^{\circ}$ away from the axial part of the mountains producing in places $>2 \mathrm{~km}$ of 
uplift of the base of the lava sheets (Parrish, 1983). These lavas therefore provide a well constrained upper age limit for the surface uplift in the Coast Range Mountains of British Columbia. Similarly, in the Washington Cascades to the south (Fig. 2), Middle Miocene ( $\sim 15 \mathrm{Ma}$ ) lavas are tilted and uplifted in the eastern Cascades and reach elevations near Mount Rainer that are $1.5 \mathrm{~km}$ higher than similar units exposed further to the east (Swanson, 1997). In addition, in numerous locations, sedimentary rocks of Miocene age demonstrate that regional warping and uplift occurred post $15 \mathrm{Ma}$ (e.g. Reidel et al., 1994).

Finally, low temperature thermochronometric studies have been conducted at numerous places in the western Cordillera from $47^{\circ} \mathrm{N}$ to $63^{\circ} \mathrm{N}$ (as summarised in Reiners et al., 2002 and references therein; Fig. 2). These studies constitute a regional scale database that indicates a significant acceleration of rock exhumation rates during the Late Miocene (Reiners et al., 2002; Parrish, 1983; O'Sullivan and Parrish, 1995; Fitzgerald et al., 1995; O'Sullivan and Currie, 1996; Farley et al., 2001). On its own such information should be interpreted in terms of surface uplift with caution. However, numerous studies have demonstrated that the amount of rock uplift and erosion in mountainous terranes are closely coupled with local relief (e.g. Montgomery and Brandon, 2002). This, in combination with the evidence discussed above, suggests that the acceleration in rock uplift rate during the Late Miocene of the coastal mountains north of $\sim 47^{\circ} \mathrm{N}$ is, at least in part, consistent with an increase in relief and topography at this time.

In this contribution, we revisit the hypothesis of Ruddiman et al. (1989) concerning the uplift of the North American Cordillera. These authors proposed that uplift of the North American Cordillera during the Late Miocene/Early Pliocene was responsible for cooling North America and triggering the intensification of Northern Hemisphere glaciation. In contrast, Seki et al. (2010) document that INHG was triggered by orbital forcing once $p \mathrm{CO}_{2}$ had crossed the required threshold value of $\sim 280-300 \mathrm{ppm}$ (Deconto et al. 2008). Consequently, it is unlikely that mountain uplift played a direct role in triggering sustained glaciation in the Northern Hemisphere in the Pliocene. Instead, we ask in this contribution whether mountain uplift was a vital precondition to the INHG. In other words, in the absence of the mountains of the North American Cordillera would Northern Hemisphere glaciation have intensified at $\sim 3 \mathrm{Ma}$ as $p \mathrm{CO}_{2}$ declined to 280-300 ppm? We first present a new reconstruction of Miocene topography of this region and then present new modelling results of a sensitivity test using an oceanatmosphere GCM (HadCM3) and offline ice sheet model (GLIMMER). These results highlight that the climate of the Northern Hemisphere is particularly sensitive to the topography of western North America that presents itself to westerly atmospheric circulation. We show that even a relatively small change in elevation of the North American Cordillera is sufficient to cool the Northern Hemisphere and influence ice sheet coverage during cold orbital stages. If large parts of the North American Cordillera did uplift during the Late Miocene/Early Pliocene then they may have played a vital role in favouring INHG

\section{Methodology}

\subsection{Simplified topographic reconstruction}

Reconstructing the topographic evolution of a mountainous region is a rather difficult task and reconstructions such as those discussed in section 1.2 are typically contentious. Nevertheless, in the absence of better reconstructions we feel it is reasonable to suggest that some surface uplift of the North American Cordillera as a whole may have occurred since the Miocene (as suggested by Ruddiman et al., 1989). We feel however that there is considerably stronger evidence (reviewed in Sect. 1.2) to suggest that the westernmost Cordillera, north of about $45^{\circ} \mathrm{N}$, has undergone significant surface uplift since the Late Miocene. In order to model the influence of this uplift on climate, we have approximated the Early-Middle Miocene topography of the North American Cordillera (Fig. 3). To make this reconstruction we uniformly truncated the North American topography north of $45^{\circ} \mathrm{N}$ at $750 \mathrm{~m}$, retaining modern surface roughness. Due to the spatial resolution of the model, this is roughly equivalent to reducing the average height of these ranges by $\sim 500 \mathrm{~m}$. Although this is in keeping with the geological evidence for pre-Pliocene surface uplift, we acknowledge such topography may never have existed in this simplified form. Figure $3 \mathrm{c}$ shows the topographic differences between the modern day topography (at model resolution) and our approximation of the Early-Middle Miocene North American Cordillera.

\subsection{GCM simulations and ice sheet models}

All the GCM simulations described in this paper are carried out using the UK Met Office ocean-atmosphere GCM (HadCM3, version 4.5, Gordon et al., 2000). The resolution of the atmospheric and land components is $3.75^{\circ}$ in longitude by $2.5^{\circ}$ in latitude, with 19 vertical levels in the atmosphere. The resolution of the ocean model is $1.25^{\circ}$ by $1.25^{\circ}$ with 20 levels in the vertical. Parameterisations include the radiation scheme of Edwards \& Slingo (1996), the convection scheme of Gregory et al. (1997), and the MOSES-1 land-surface scheme, whose representation of evaporation includes the dependence of stomatal resistance on temperature, vapour pressure and $\mathrm{CO}_{2}$ concentration (Cox et al., 1999). The ocean model uses the Gent and McWilliams (1990) mixing scheme. There is no explicit horizontal tracer diffusion in the model. The horizontal resolution allows the use of a smaller coefficient of horizontal momentum viscosity leading to an improved simulation of ocean velocities compared to earlier versions of the model. The sea ice model uses a 
Table 1. Detail of experiments and a comparison with those of Lunt et al. (2008a).

\begin{tabular}{cccccc}
\hline & Control & low-45 & L08-control & L08-low $\mathrm{CO}_{2}$ & L08-uplift \\
\hline & & Low mnts. & Low & Low & \\
Orography & Modern & North of $45^{\circ} \mathrm{N}$ & $\begin{array}{c}\text { N. American } \\
\text { Cordillera }\end{array}$ & $\begin{array}{c}\text { N. American } \\
\text { Cordillera }\end{array}$ & Modern \\
Vegetation & Modern & Modern & Pliocene & Pliocene & Pliocene \\
$\mathrm{CO}_{2}$ (ppmv) & 280 & 280 & 400 & 280 & 400 \\
$\mathrm{CH}_{4}(\mathrm{ppbv})$ & 760 & 760 & 760 & 760 & 760 \\
& & & Pliocene & Pliocene & Pliocene \\
Ice & Modern & Modern & reduced & reduced & reduced \\
& & & Greenland & Greenland & Greenland \\
\hline
\end{tabular}

simple thermodynamic scheme and contains parameterisations of ice concentration (Hibler, 1979) and ice drift and leads (Cattle \& Crossley, 1995), but neglects elastic-viscousplastic effects. In simulations of the present-day climate, the model has been shown to simulate SST in good agreement with modern observations without the need for flux corrections (Gregory \& Mitchell, 1997). This model has previously been used in several Cenozoic modelling studies (Lunt et al., 2008a, b; Lunt et al., 2009); Table 1 summarises the boundary conditions used here and highlights the differences between this and these published studies.

We carried out two coupled atmosphere-ocean GCM simulations using HadCM3 version 4.5. We initially carried out a pre-industrial control simulation with modern orography (smoothed to the model resolution of $3.75^{\circ}$ longitude by $2.5^{\circ}$ latitude). A further simulation, termed "low- $45 \mathrm{~N}$ ", with a reduced topography (shown in Fig. 3b) was then carried out. In all other regards this perturbed simulation had identical boundary conditions (prescribed $p \mathrm{CO}_{2}$, ice sheet and vegetation) to the pre-industrial control simulation. Compared to a faster model of intermediate complexity, such as CLIMBER (Bonelli et al., 2009), this model allows a more accurate representation of global topography. However, the limited model spin up time of "low-45N" (50 years i.e. < ocean overturning) means only changes in atmospheric circulation and the ocean mixed layer can be examined, in a similar way to if we had used a slab ocean model.

Although the climate model used allows a more accurate simulation of climate than intermediate complexity models, it is computationally intensive and this precludes the full coupling of an ice sheet model to the GCM. We have used an offline ice sheet model, following Lunt et al. (2008a), to examine the effect of mountain uplift on Laurentide and Cordilleran Ice Sheet inception only. However, because these offline ice sheet simulations do not include crucial feedbacks (e.g. albedo feedback), it is important to note that the ice sheets simulated represent minimum configurations. Therefore, although the simulated ice sheets are much smaller than those in fully coupled models, they can still provide infor- mation regarding glacial inception (e.g. Lunt et al., 2008a). These limitations, in addition to the fact that we did not use a palaeogeography explicitly appropriate for the Miocene, mean this study should be viewed strictly as a sensitivity study examining the effects of mountain uplift in isolation. The changes we observe and apply significance to are those of a first order nature and, although this study does have implications for Miocene climate, it should be noted that we are not trying to explicitly replicate the climate of the Late Miocene.

The 3-D thermomechanical ice sheet model used in this work is GLIMMER version 1.0.4. The core of the model is based on the ice sheet model described by Payne (1999; see Rutt et al., 2009 for a full description of the model). The ice dynamics are represented with the widely-used shallow-ice approximation, and a full three-dimensional thermodynamic model is used to determine the ice flow law parameter (see Sect. 3 of Rutt et al., 2009). The model is formulated on a $20 \mathrm{~km}$ Cartesian $x-y$ grid and takes as input the surface mass-balance and air temperature at each time step. In the present work, the ice dynamics time step is one year. To simulate the surface mass-balance, we use the positive degree day (PDD) approach described by Reeh (1991). The use of PDD mass-balance models is well-established in coupled atmosphere-ice sheet palaeoclimate modelling studies (e.g. DeConto and Pollard, 2003, Lunt et al., 2008a, b; Lunt et al., 2009). GLIMMER includes a representation of the isostatic response of the lithosphere, which is assumed to behave elastically, based on the model of Lambeck and Nakiboglu (1980). The forcing data from HadCM3 are transformed onto the ice model grid using bilinear interpolation, which ensures that precipitation is conserved in the atmosphere-ice-sheet coupling. In the case of the surface air temperature field, a vertical lapse-rate correction is used to take account of the difference between the high-resolution topography seen within GLIMMER, and that represented with HadCM3. The use of a lapse-rate correction to better represent the local temperature is established in previous work (e.g. Pollard and Thompson, 1997). We use anomaly coupling to force the ice 

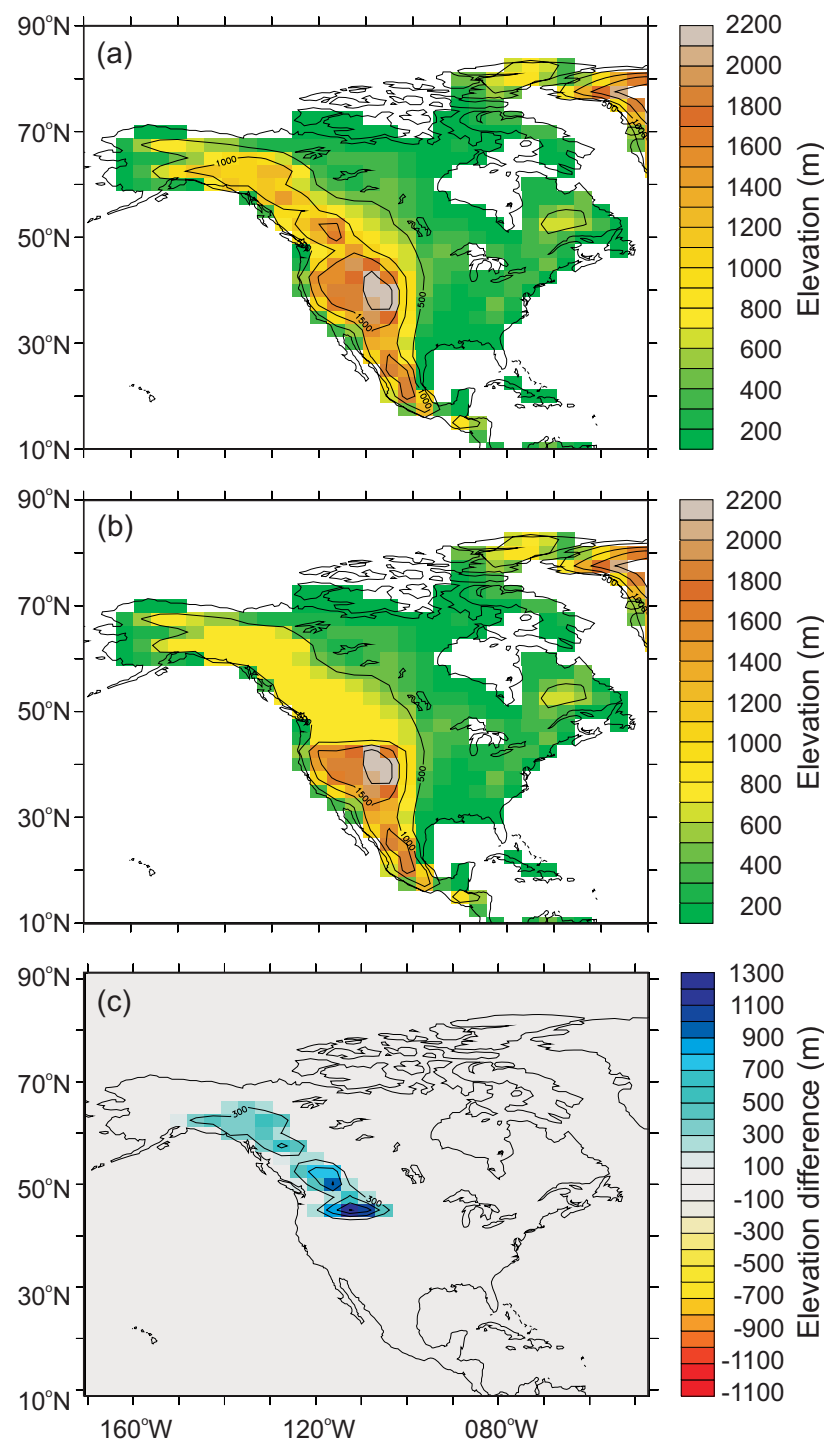

Fig. 3. Topographic boundary conditions of North America. (a) modern configuration used for the pre-industrial control; (b) "low$45 \mathrm{~N}$ " configuration; (c) anomaly plot for "low- $45 \mathrm{~N}$ " plot (modern - "low-45 N").

sheet model, and use values for the PDD factors of 0.008 for ice and $0.003 \mathrm{~m} \mathrm{day}^{-1 o} \mathrm{C}^{-1}$ for snow. The anomaly method is used to partly alleviate the cold bias in the model at high latitudes (Randall et al. 2007); although over North America the bias is relatively low (less than $2{ }^{\circ} \mathrm{C}$ ). For the baseline climate to which the anomalies are applied, we use a standard temperature and precipitation climatology derived from ERA-40 reanalysis. The GLIMMER ice sheet model uses a single value for the lapse-rate correction which we set to a value of $7.0 \mathrm{~K} \mathrm{~km}^{-1}$. For the standard pre-industrial ice sheet simulations, we use the bedrock topography derived from the standard ETOPO5 dataset. For the "low-45 N" simulation, we truncated mountains along the west coast to $750 \mathrm{~m}$ north- wards of $\sim 45^{\circ} \mathrm{N}$, in a similar way as in the corresponding GCM simulation.

Because the timescale for equilibrium of the North American ice sheets is comparable with orbital timescales, it is important to carry out transient ice sheet simulations which include orbital effects. We use a time variable orbital anomaly representing the insolation experienced during a transition from near-average orbital conditions to glacial orbital conditions and back again, over half a precessional cycle, that is, 10000 years. In order to do this, we carry out an additional GCM simulation under "cold-orbit" forcing; that is orbital conditions for $115 \mathrm{kyr} \mathrm{BP}$, but otherwise pre-industrial boundary conditions. This gives us an anomaly relative to pre-industrial which represents the maximum orbital forcing over the 10000 years. Then, for the final ice sheet simulations, we use the original GCM climate ("pre-industrial control" and "low-45N"), superimposed with the time-varying orbital component. More details of this approach can be found in Lunt et al. (2008a).

\section{Results}

Figure 4 shows the magnitude of surface air temperature (at $2 \mathrm{~m}$ ), precipitation, snow accumulation, and surface albedo warm and cold season anomalies for the reduced topography simulation. In all cases, the anomalies are for the "preindustrial control" minus the "low- $45 \mathrm{~N}$ " simulation, therefore reflecting changes associated with uplift and the establishment of the modern orography. From these figures, the local and more distant hemispheric effects of uplift are clearly observable. For instance, the uplifted area is colder (Fig. 4a, b), and to the west of the uplifted area, precipitation and temperature have clearly increased (Fig. 4c, d) reflecting the intensification of orographic precipitation. There are also several far-field effects that warrant further discussion. The most significant observation is the strong winter but rather weak summer cooling of the NE American continent and the Canadian Arctic (Fig. 4a, b); this results in a minor increase in sea-ice extent off Greenland, and an associated increase in albedo (Fig. 4e, f). These far-field temperature lows are coincident with the $500 \mathrm{mb}$ height anomaly (not shown) implying that the mountain uplift led to a deepening of the Rossby wave trough over this region. The consequent modification of storm tracks is also visible on the precipitation anomaly (Fig. 4c, d), which shows a predominantly winter reduction in the penetration of storms and associated precipitation in the continental interior and reduced precipitation over parts of Greenland and NE Canada.

Figure 5 shows the results of the ice sheet model described above, in conjunction with an additional cold-orbit GCM simulation, for the control (Fig. 5a) and "low-45 N" simulation (Fig. 5b). In the control (cold-orbit) simulation (Fig. 5a), unsurprisingly, the ice sheet model predicts the inception of ice sheets in the islands of the Canadian Arctic and in the 

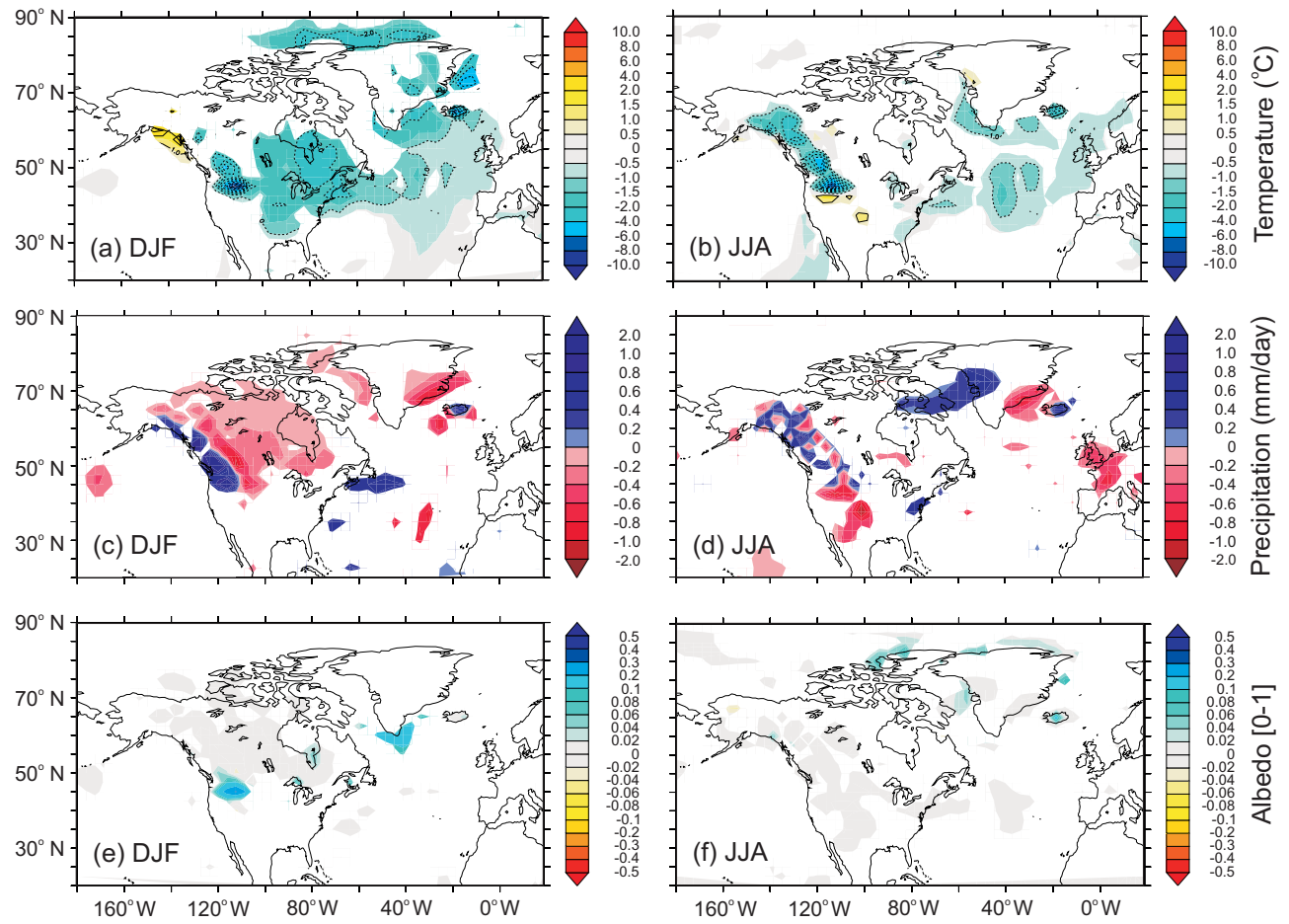

Fig. 4. Seasonal (December-January-February and June-July-August) anomalies of pre-industrial control minus "low-45 N" configuration (i.e. reflecting the climate change as a consequence of mountain uplift). (a, b) surface air temperature at $2 \mathrm{~m}$ [degrees $\mathrm{C}$ ]; (c, d) precipitation $[\mathrm{mm} /$ day]; (e, f) surface albedo. White colouring shows regions where the interannual variability is such that there is no statistically significant change, as indicated by a Student $\mathrm{T}$ test with a $95 \%$ confidence threshold.
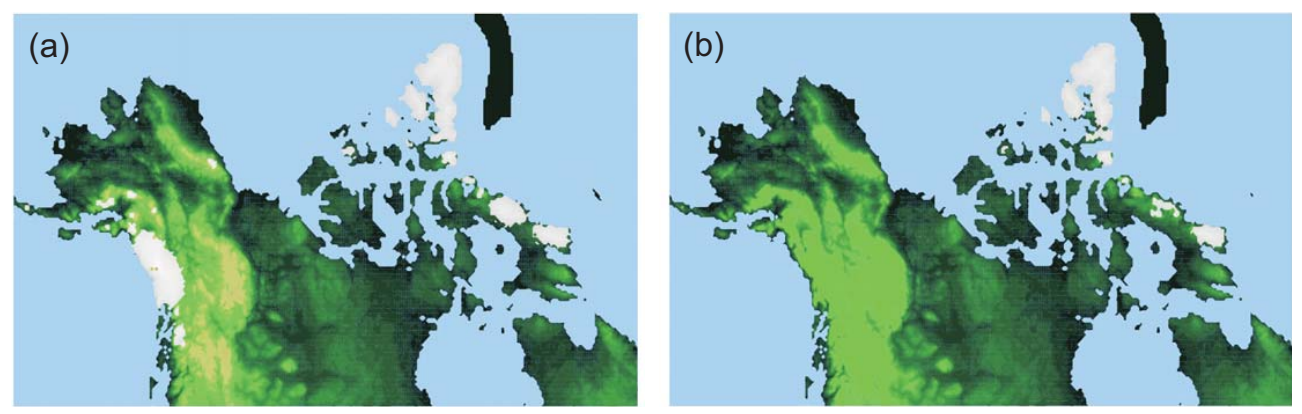

Fig. 5. Ice sheet configurations for the (a) pre-industrial control and (b) "low- 45 N" mountains simulations (see text for details).

high mountains of the NW Cordillera. It is important to note that, since the ice sheet model is not fully coupled to the GCM, the positive feedbacks relating to ice growth are not represented so the ice sheets shown are minima (see Lunt et al., 2008a for further discussion). It is, however, clear that, due to temperature changes associated with uplift, in the "low-45 N" simulation with reduced topography (Fig. 4a, b), no Cordilleran Ice Sheet forms and there is a minor reduction of ice on Baffin Island.

\section{Discussion and conclusions}

The most significant results of this study are the strong year round cooling in the region uplifted (Fig. 4). In terms of ice sheet response, with reduced mountains, the Cordilleran Ice Sheet fails to incept entirely and the amount of ice on Baffin Island is slightly reduced (Fig. 5). For the Cordilleran ice sheet, this change is largely caused by the direct effect of elevation change, i.e. given a lapse rate of $7.0 \mathrm{~K} \mathrm{~km}^{-1}$ a $\sim 500 \mathrm{~m}$ reduction in height would cause a $\sim 3.5^{\circ} \mathrm{C}$ warming (Fig. 4). For Baffin Island there are no significant climatological anomalies associated with this reduction in the ice sheet, suggesting this may be an 
artefact related to interannual variability in the driving climate (Fig. 4). Nonetheless, the modelled response of the Cordilleran Ice sheet to uplift is large, and this may have had a significant impact on the growth of ice in the Northern Hemisphere as a whole through ice sheet-climate feedbacks (e.g. the albedo feedback and through atmospheric and ocean circulation). Lunt et al. (2008a) examined the influence of Cordilleran uplift on ice sheet growth on Greenland during the Mid Pliocene using an offline ice sheet model similar to that used here. They used a $p \mathrm{CO}_{2}$ value of $400 \mathrm{ppmv}$, and a more extreme uplift scenario (see Table 1), and concluded that uplift was not sufficient, on its own, to significantly enhance Greenland glaciation when compared to the effect of lowering $p \mathrm{CO}_{2}$ to $280 \mathrm{ppmv}$. Nevertheless, Lunt et al. (2008a) did model a small increase in the ice present on Greenland as a result of the cooling and precipitation changes similar to those shown in Fig. 4. The initial ice-sheet prescribed in the GCM simulations used in that study was larger than the one grown following uplift. Therefore, in that case the results are a maximum response and imply only a small growth of the Greenland ice sheet following uplift.

There are also several important regional and far-field climatic shifts evident in our GCM results that are consistent with existing studies of the Miocene climate. This, therefore, provides additional support for there being a period of Cordilleran mountain uplift in the Late Miocene. For instance, perhaps the most regionally significant far-field anomalies are the changes in precipitation patterns and the development of a rainy season (decrease in summer) in the continental interior of the US (Fig. 4d). There are a number of studies that document such a climatic shift occurring during the Late Miocene, for instance Retallack (1997) notes a marked drying in fossil paleosols and an expansion of the American Prairie in the Late Miocene. Similarly, Fox (2000), using mammalian fossils, documents a drying of the North American continent associated with an increase in seasonality in the Late Miocene, including the development of a wet season. Kohn and Fremd (2008) also record a decrease in faunal diversity in the Western US between 12 and $7 \mathrm{Ma}$ thought to coincide with increased aridity and seasonality.

A puzzling aspect of Late Cenozoic climate is that despite generally low $\mathrm{CO}_{2}$ during the last 25 million years (Fig. 1), the prolonged glaciation of the North America and the Northern Hemisphere in general did not occur until $\sim 3$ million years ago (Ruddiman, 2010). Our simulations imply that a reduction in the height of the North American Cordillera influences North American climate and likely limits the glaciation of North America. Since we do not have a fully coupled GCM-ice sheet model, we cannot determine exactly how these changes in topography influence the level of $\mathrm{CO}_{2}$ required to allow orbital forcing to kick-start INHG. Similarly, our choice of initial climate state and model spin up time precludes a more complete discussion of Miocene climate change. Nonetheless, given the direction of the climate trends described here, we can say with confidence that the threshold $\mathrm{CO}_{2}$ value required is lower when the height of the North American Cordillera is reduced. It has been suggested that the intensification of Northern Hemisphere Glaciation occurred in several stages over a relatively protracted period (Maslin et al., 1998, Mudlesee and Raymo, 2005), these were: (i) early glaciation of Greenland from 3 to $3.8 \mathrm{Ma}$; (ii) glaciation of Eurasian Arctic and the North American Cordillera from 2.70 to $2.74 \mathrm{Ma}$; and (iii) glaciation of Eurasia and North America at $\sim 2.55 \mathrm{Ma}$ (e.g. Balco and Rovey, 2010). In the absence of a Cordilleran Ice Sheet, and its associated albedo related cooling, this sequence may be prevented from running to completion. Consequently, a lower North American Cordillera may have played a crucial role in preventing glaciation of North America during the Middle and Early Miocene, despite relatively low $\mathrm{CO}_{2}$ levels during these time periods (Fig. 1). Also, it is important to note that uplift of the North American Cordillera did not occur in isolation; rather it seems a number of areas suffered regional uplift in the Late Miocene (e.g. Tibet, Andes, SW Africa). Other published studies suggest that uplift in these areas was also associated with regional and far-field climatic change (e.g. Sepulchre et al., 2006; Lunt et al., in press). However, until better palaeotopographic reconstructions are available, the exact role of mountain uplift in influencing Late Cenozoic climate evolution will continue to be uncertain and relatively unconstrained in magnitude when compared to other environmental factors. Reconstructions of past palaeotopography are thus an important uncertainty in modelling climate dynamics in the past and this should be addressed.

Acknowledgements. The Natural Environment Research Council is acknowledged for providing funding for this contribution in the form of a NERC fellowship to GLF. DJL is funded by BAS and RCUK fellowships. RP acknowledges support from NERC during the evolution of this contribution. A. Carter and C. Barnes are also thanked for their comments on an earlier draft of this manuscript.

Edited by: V. Rath

\section{References}

Balco, G. and Rovey, C. W., II: Absolute chronology for major pleistocene advances of the laurentide ice sheet, Geology, 38, 795-798, 10.1130/G30946.1, 2010.

Bonelli, S., Charbit, S., Kageyama, M., Woillez, M.-N., Ramstein, G., Dumas, C., and Quiquet, A.: Investigating the evolution of major Northern Hemisphere ice sheets during the last glacialinterglacial cycle, Clim. Past, 5, 329-345, doi:10.5194/cp-5-3292009, 2009.

Broccoli, A. J. and Manabe, S.: The effects of orography on midlatitude Northern Hemisphere dry climates, J. Climate, 5, 11811201, 1992.

Broccoli, A. J. and Manabe, S.: Mountains and midlatitude aridity, in: Tectonic uplift and climate change, edited by: Ruddiman, W. F., Plenum Press, NY, USA, 89-121, 1997. 
Burchfiel, B. C., Cowan, D. S., and Davis, G. A.: Tectonic overview of the cordilleran orogen in the western united states, in: The cordilleran orogen: Conterminous US, edited by: Burchfiel, B. C., Lipman, P. W., and Zoback, M. L., Geological Society of America, The Geology of North America, Boulder, Colorado, USA, 407-479, 1992.

Campbell, R. B. and Dodds, C. J.: Operation St. Elias, Yukon Territory, Geological Survey of Canada, Paper, 78-1a, 35-41, 1978.

Cattle, H. and Crossley, J.: Modelling arctic climate change, Phil. Trans. Royal Soc., A352, 201-213, 1995.

Chamberlain, C. P. and Poage, M. A.: Reconstructing the paleotopography of mountain belts from the isotopic composition of authigenic minerals, Geology, 28, 115-118, 2000.

Clague, J. J.: Quaternary glaciation and sedimentation, in: Geology of the cordilleran orogen in Canada, edited by: Gabrielse, H., and Yorath, C. J., Geological Survey of Canada, Ottawa, Canada, 419-434, 1991.

Cox, P., Betts, R., Bunton, C., Essery, R., Rowntree, P. R., and Smith, J.: The impact of new land-surface physics on the GCM simulation and climate sensitivity, Clim. Dynam., 15, 183-203, 1999.

DeConto, R. M. and Pollard, D.: Rapid Cenozoic glaciation of Antarctica induced by declining atmospheric $\mathrm{CO}_{2}$, Nature, 421, 245-249, 2003.

DeConto, R. M., Pollard, D., Wilson, P. A., Palike, H., Lear, C. H., and Pagani, M.: Thresholds for Cenozoic bipolar glaciation, Nature, 455(7213), 652-656, doi:10.1038/nature07337, 2008.

Denton, G. H. and Armstrong, R. L.: Miocene-Pliocene glaciations in southern Alaska, Am. J. Sci., 267, 1121-1142, 1969.

Edwards, J. M. and Slingo, A.: Studies with a flexible new radiation code 1: Choosing a configuration for a large-scale model, Q. J. Roy. Meteorol. Soc., 122, 689-719, 1996.

England, P. and Molnar, P.: Surface uplift, uplift of rocks and exhumation of rocks, Geology, 18, 1173-1177, 1990.

Farley, K. A., Rusmore, M. E., and Bogue, S. W.: Post 10-ma uplift and exhumation of the northern Coast Mountains, British Columbia, Geology, 29, 99-102, 2001.

Fitzgerald, P. G., Sorkhabi, R. B., Redfield, T. F., and Stump, E.: Uplift and denudation of the central Alaska Range: A case study in the use of fission track thermochronology to determine absolute uplift parameters, J. Geophys. Res., 100, 20175-20191, 1995.

Fox, D. L.: Growth increments in gomphotherium tusks and implications for late Miocene climate change in North America, Palaeogeogr. Palaeoclim. Palaeoecol., 156, 327-348, 2000.

Garizone, C. N., Hoke, G. D., Libarkin, J. C., Withers, S., MacFadden, B., Eiler, J., Ghosh, P., and Mulch, A.: Rise of the Andes, Science, 320, 1304-1307, 2008.

Gent, P. R. and McWilliams, J. C.: Isopycnal mixing in ocean circulation models, J. Phys. Oceanogr., 20, 150-155, 1990.

Gordon, C., Cooper, C., Senior, C. A., Banks, H., Gregory, J. M., Johns, T. C., Mitchell, J. F. B., and Wood, R. A.: The simulation of SST, sea ice extents and ocean heat transports in a version of the hadley centre coupled model without flux adjustments, Clim. Dynam., 16, 147-168, 2000.

Gregory, D., Kershaw, R., and Inness, P. M.: Parametrisation of momentum transport by convection ii: Tests in single column and general circulation models, Q. J. Roy. Meteorol. Soc., 123, 1153-1183, doi:10.1002/qj.49712354103, 1997.
Gregory, J. M. and Mitchell, J. F. B.: The climate response to $\mathrm{CO}_{2}$ of the hadley centre coupled AOGCM with and without flux adjustment, Geophys. Res. Lett., 24, 1943-1946, 1997.

Hibler, W. D.: A dynamic thermodynamic sea ice model, J. Phys. Oceanogr., 9, 815-846, 1979.

Horton, T. W., Sjostrom, D. J., Abruzzese, M. J., Poage, M. A., Waldbauer, J. R., Hren, M., Wooden, J., and Chamberlain, C. P.: Spatial and temporal variation of Cenozoic surface elevation in the Great Basin and Sierra Nevada, Am. J. Sci., 304, 832-888, 2004.

Hyndman, R. D., Currie, C. A., and Mazzotti, S. P.: Subduction zone backarcs, mobile belts, and orogenic heat, GSA Today, 15, 4-10, 2005.

Kent-Corson, M. L., Sherman, L. S., Mulch, A., and Chamberlain, C. P.: Cenozoic topographic and climatic response to changing tectonic boundary conditions in western North America, Earth Planet. Sci. Lett., 252, 453-466, 2006.

Kohn, M. J. and Fremd, T. J.: Miocene tectonics and climate forcing of biodiversity, western United States, Geology, 36, 783-786, doi:710.1130/G24928A.24921, 2008.

Kohn, M. J., Miselis, J. L., and Fremd, T. J.: Oxygen isotope evidence for progressive uplift of the Cascade Range, Oregon, Earth Planet. Sci. Lett., 204, 151-165, 2002.

Kürschner, W. M., van der Burgh, J., Visscher, H., and Dilcher, D. L.: Oak leaves as biosensors of Late Neogene and Early Pleistocene paleoatmospheric $\mathrm{CO}_{2}$ concentrations, Mar. Micropalentol., 27, 299-312, 1996.

Kürschner, W. M., Kvacek, Z., and Dilcher, D. L.: The impact of Miocene atmospheric carbon dioxide fluctuations on climate and the evolution of terrestrial ecosystems, PNAS, 105, 440-453, 2008.

Kutzbach, J. E., Guetter, P. J., Ruddiman, W. F., and Prell, W. L.: Sensitivity of climate to Late Cenozoic uplift in southern Asia and the American West: Numerical experiments, J. Geophys. Res., 94, 18393-18407, 1989.

Lambeck, K. and Nakiboglu, S. M.: Seamount loading and stress in the ocean lithosphere, J. Geophys. Res., 85, 6403-6418, 1980.

Lunt, D. J., Haywood, A. M., Foster, G. L., and Stone, E. J.: The arctic cryosphere in the mid-pliocene and the future, Phil. Trans. Roy. Soc. A, doi:10.1098/rsta.2008.0218, 2009.

Lunt, D. J., Foster, G. L., Haywood, A. M., and Stone, E. J.: Late Pliocene Greenland glaciation controlled by a decline in atmospheric $\mathrm{CO}_{2}$ levels, Nature, 454, 1102-1105, $2008 \mathrm{a}$.

Lunt, D. J., Valdes, P. J., Haywood, A. M., and Rutt, I. C.: Closure of the Panama Seaway during the Pliocene: Implications for climate and Northern Hemisphere Glaciation, Clim. Dynam. 30, 1-18, 2008b.

Lunt, D. J., Flecker, R., and Clift, P. D.: The impacts of Tibetan uplift on palaeoclimate proxies, Geol. Soc. London, in press, 2010.

Martin, H. E. and Rouse, G. E.: Palynology of late tertiary sediments from Queen Charlotte Islands, British Columbia, Can. J. Bot., 44, 171-208, 1966.

Montgomery, D. R. and Brandon, M. T.: Topographic controls on erosion rates in tectonically active mountain ranges, Earth Planet. Sci. Lett., 673, 1-9, 2002.

Mudelsee, M. and Raymo, M. E.: Slow dynamics of the Northern Hemisphere Glaciation, Paleoceanography, 20, PA4022, doi:10.1029/2005PA001153, 2005. 
O'Sullivan, P. B. and Parrish, R. R.: The importance of apatite composition and single-grain ages when interpreting fission-track data from plutonic rocks: A case study from the Coast Ranges, British Columbia, Earth Planet. Sci. Lett., 132, 213-224, 1995.

O'Sullivan, P. B. and Currie, L. D.: Thermotectonic history of Mt Logan, Yukon territory, Canada: Implications of multiple episodes of Middle to Late Cenozoic denudation, Earth Planet. Sci. Lett., 144, 251-261, 1996.

Pagani, M., Freeman, K. H., and Arthur, M. A.: Late Miocene atmospheric $\mathrm{CO}_{2}$ concentrations and the expansion of $\mathrm{C}_{4}$ grasses, Science, 285, 876-879, 1999.

Pagani, M., Lemarchand, D., Spivack, A., and Gaillardet, J.: A critical evaluation of the boron isotope- $p \mathrm{H}$ proxy: The accuracy of ancient $p \mathrm{H}$ estimates, Geochim. Cosmochim. Acta, 69, 953-961, 2005.

Pagani, M., Liu, Z., LaRiviere, J., and Ravelo, A. N.: High Earth-system climate sensitivity determined from Pliocene carbon dioxide concentrations, Nature Geosci., 3, 27-30, 2009.

Parrish, R. R.: Cenozoic thermal evolution and tectonics of the coast mountains of British Columbia 1. Fission-track dating, apparent uplift rates, and patterns of uplift, Tectonics, 2, 601-631, 1983.

Parrish, R. R., Carr, S. D., and Parkinson, D. L.: Eocene extensional tectonics and geochronology of the southern Omineca Belt, British-Columbia and Washington, Tectonics, 7, 181-212, 1988.

Passey, B. H., Cerling, T. E., Perkins, M. E., Voorhies, M. R., Harris, J. M., and Tucker, S. T.: Environmental change in the Great Plains: An isotopic record from fossil horses, J. Geol., 110, 123139, 2002.

Payne, A. J.: A thermomechanical model of ice flow in west antarctica, Climate Dynamics, 15, 115-125, 1999.

Pearson, P. N. and Palmer, M. R.: Atmospheric carbon dioxide concentrations over the past 60 million years, Nature, 406, 695-699, 2000.

Pollard, D. and Thompson, S. L.: Driving a high-resolution dynamic ice sheet model with gcm climate: Ice-sheet initiation at 116000 bp, Ann. Glaciol., 25, 296-304, 1997.

Randall, D. A., Wood, R. A., Bony, S., Colman, R., Fichefet, T., Fyfe, J., Kattsov, V., Pitman, A., Shukla, J., Srinivasan, J., Stouffer, R. J., Sumi, A., and Talyor, K. E.: Climate models and their evaluation, in: Cilmate Models and Their Evaluation. In: Climate Change 2007: The Physical Science Basis. Contribution of Working Group I to the Fourth Assessment Report of the Intergovernmental Panel on Climate Change, edited by: Soloman, S., Qin, D., Manning, M., Chen, Z., Marquis, M., Averyt, K. B., Tignor, M., and Miller, H. L., Cambridge University Press, Cambridge, UK, 2007.

Raymo, M. E., Ruddiman, W. F., and Froelich, P. N.: Influence of Late Cenozoic mountain building on ocean geochemical cycles, Geology, 16, 649-653, 1988.

Raymo, M. E. and Ruddiman, W. F.: Tectonic forcing of Cenozoic climate, Nature, 359, 117-122, 1992.

Reeh, N.: Parameterization of melt rate and surface temperature on the Greenland ice sheet, Polarforschung, 59, 113-128, 1991.

Reidel, S. P., Campbell, N. P., Fecht, K. R., and Lindsey, K. A.: Late Cenozoic structure and stratigraphy of south-central Wasthington, Washington Division of Geology and Earth Resources Bulletin, 80, 159-180, 1994.
Reiners, P. W., Ehlers, T. A., Garver, J. I., Gran Mitchell, S., Montgomery, D. R., Vance, J. A., and Nicolescu, S.: Late miocene exhumation and uplift of the washington cascade range, Geology, 30, 767-770, 2002.

Retallack, G. J.: Neogene expansion of the North American prairie, Palios, 12, 380-390, 1997.

Retallack, G. J.: Late Oligocene bunch grassland and Early Miocene sod grassland paleosols from central Oregon, USA, Palaeogeogr. Palaeoclim. Palaeoecol., 207, 203-237, 2004.

Rouse, G. E. and Mathews, W. H.: Tertiary geology and palynology of the Quesnel area, British Columbia, B. Can. Petrol. Geol., 27, 418-445, 1979.

Rowley, D. B. and Garizone, C. N.: Stable isotope-based Paleoaltimetry, Ann. Rev. Earth Planet. Sci, 35, 463-508, 2007.

Ruddiman, W. F. and Kutzbach, J. E.: Forcing of the Late Cenozoic Northern Hemisphere climate by plateau uplift in southern Asia and the America West, J. Geophys. Res., 94, 18409-18427, 1989.

Ruddiman, W. F.: A Paleoclimatic Enigma?, Science, 328, 838839, 2010.

Rutt, I. C., Hagdorn, M. H., Hulton, N. R. J., and Payne, A. J.: The Glimmer community ice sheet model, J. Geophys. Res., 114, F02004, doi:10.1029/2008JF001015, 2009.

Sahagian, D., Proussevitch, A., and Carlson, W.: Timing of Colorado plateau uplift: Initial constraints from vesicular basaltderived paleoelevations, Geology, 30, 807-810, 2002.

Seager, R., Battisti, D. S., Yin, J., Gordon, N., Naik, N., Clement, A. C., and Cane, M. A.: Is the gulf stream responsible for europe's mild winters, Q. J. R. Meterol. Soc., 128, 2563-2586, 2002.

Seki, O., Foster, G. L., Schmidt, D. N., Mackensen, A., Kawamura, K., and Pancost, R. D.: Alkenone and boron based PlioPleistocene $\mathrm{pCO}_{2}$ records, Earth Planet. Sci. Lett., 292, 201-211, 2010.

Souther, J. G. and Yorath, C. J.: Neogene assemblages, in: Geology of the Cordilleran Orogen in Canada, edited by: Gabrielae, H., and Yorath, C. J., Geol. Surv. Can., Geol. Canada, 373-401, 1992.

Supulchre, P., Ramstein, G., Fluteau, F., Schuster, M., Tiercelin, J.-J., and Brunet, M.: Tectonic uplift and Eastern Africa aridification, Science, 313, 1419-1423, 2006.

Swanson, D. A.: Uplift of the southern Washington Cascades in the past 17 million years, Geological Society of America Abstracts with Programs, 29, 68, 1997.

Takeuchi, A. and Larson, P. B.: Oxygen isotope evidence for the Late Cenozoic development of an orographic rain shadow in eastern Washington, USA, Geology, 33, 313-316, 2005.

White, J. M., Ager, T. A., Adam, D. P., Leopold, E. B., Liu, G., Jette, H., and Schweger, C. E.: An 18 million year record of vegetation and climate change in northwestern Canada and Alaska: Tectonic and global climatic correlates, Palaeogeogr. Palaeoclim. Palaeoecol., 130, 293-306, 1997.

Winkler, A.: The climate history of the high northern latitudes since the middle Miocene: Indications from sedimentological and clay mineralogical analyses (ODP leg 151, central Fram strait), Reports on Polar Research, Alfred Wegener Institute for Polar and Marine Research, Bremerhaven, Germany, 344, 117 pp., 1999.

Wolfe, J. A., Forest, C. E., and Molnar, P.: Paleobotanical evidence of Eocene and Oligocene paleoaltitudes in midlatitude western North America, Geol. Soc. Am. Bull., 110, 664-678, 1998. 
Zachos, J., Pagani, M., Sloan, L., Thomas, E., and Billups, K.: Trends, rhythms, and aberrations in global climate $65 \mathrm{Ma}$ to present, Science, 292, 686-693, 2001.
Zachos, J. C., Dickens, G. R., and Zeebe, R. E.: An Early Cenozoic perspective on greenhouse warming and carbon-cycle dynamics, Nature, 451, 279-283, doi:10.1038/nature06588, 2008. 